407 «Геологическое доизучение, гидрогеологическая съемка с геоэкологическими исследованиями в пределах листов L-38-XI (Эрдниевский) и L-38-XII (Енотаевка) м-б 1:200000». Приволжская гидрогеологическая экспедиция ФГУГП «Волгагеология». - Астрахань, 2002 г.

5. Леонтьев О.К., Фотеева Н.И. Геоморфология и история развития северного побережья Каспийского моря: отчет о геоморфологических исследованиях в Прикаспии в 1958-1961 гг. - М.: Изд-во МГУ, 1965. $-152 \mathrm{c}$.

6. Православлев П.А. Бакинские пласты в Низовом Поволжье // Ежегодник по геологии и минералогии России. - 1908. - Т. Х. - Вып. 1-2.

7. Православлев П.А. Предисловие к статье В.И. Громовой. // Тр. Комис. по изуч. четвертич. периода. 1932. - Вып. 2. - С. 69-73.

8. Свиточ А.А., Янина Т.А. Материалы по стратотипам региональных и местных подразделений каспийского неоплейстоцена и голоцена // Стратиграфия Геологическая корреляция. - 2007. - Т. 15. - № 5. С. $95-112$

9. Седайкин В.М. Опорные разрезы четвертичных отложений Северо-Западного Прикаспия. Деп. // ВИНИТИ, № 1594-В-88. - 1988. - 190 с.

10. Смагин Б.Н., Трояновский С.В., Бушуева В.П., Кузнецова В.И., Шадрухин А.В. Отчет по комплексной геолого-гидрогеологической и инженерногеологической съемке масштаба 1:200000 листов L-38XI, XII. - Астраханская комплексная геологическая экспедиция НВ ТГУ. - 1977 г.

11. Фёдоров П.В. О четвертичной истории Каспийского моря. // Известия Всесоюз. Географического общества. - 1946. - Т. 78. - № 4. - С. 448-449.

12. Фёдоров П.В. Стратиграфия четвертичных отложений и история развития Каспийского моря. - М.: Изд-во АН СССР, 1957. - 298 с. (Труды геологического института. Вып. 10).

13. Шкатова В.К. Отчет по теме №139 «Изучение опорных разрезов четвертичных отложений СССР с целью разработки местных стратиграфических схем». Опорный разрез Западного Казахстана. ВСЕГЕИ, Ленинград. - 1973 г.

14. Янина Т.А. Дидакны Понто-Каспия. - Смоленск: Маджента, 2005. 300 с.

15. Янина Т.А. Палеогеография бассейнов Понто-Каспия в плейстоцене по результатам малакофаунистического анализа. Автореф. дисс. на соискание ученой степени доктора географ. наук. М., $2009.42 \mathrm{c}$.

16. Gromov V.I., Alekseev M.N., Vangengeim E.A., Kind N.V., Nikiforova K.V., and Ravskii E.I. Correlation scheme for Anthropogene deposits of northern Eurasia. In K.V. Nikiforova (ed.), Correlation of Anthropogene deposits of Northern Eurasia. Abstr. VII Congress of INQUA. - M.: Nauka, 1965. - P. 5-33.

17. Nevesskaja L.A. History of the Genus Didacna (Bivalvia: Cardiidae) // Paleontological Journal. - 2007. V. 41. - N 9. - P. 861-949.

\title{
PALEOECOLOGICAL HABITAT OF THE LATE QUATERNARY MOLLUSCS OF THE NORTHERN FORE-CASPIAN LOWLAND ON THE EXAMPLE OF THE KOSIKA 1 LOCALITY
}

\section{(C) 2015}

R.N. Miftakhova, candidate for a Master's degree, Department of bioecology and biological education Bashkir state pedagogical University, Ufa (Russia)

G.A. Danukalova, candidate of geological-mineralogical Sciences, head of laboratory of the Cenozoic Geology Institute of Geology, Ufa scientific center, Russian Academy of Sciences, Ufa (Russia)

Annotation. Investigations of the Middle-Late Neopleistocene deposits of the Kosika 1 locality and studied malacological complexes permit to understand changes of the main geological events of the territory and to identify molluscs palaeoecologihal habitats. Brakishwater and freshwater lakes existed on the territory after Early Khazarian Sea regression (beginning of the Late Neopleistocene; layer 1). Marine deposits accumulated during Late Khazarian Sea transgression (first half of the Late Neopleistocene; layer 2). Big river (Paleo-Volga) existed after the regression of the Late Khazarian Sea. This river flow to the south in the direction of the coastline retreatment. Fluvial deposits prove river existence (layer 4). Marine deposits with special key mollusc species accumulated during the Khvalynian Sea transgression. Again, river existed after regression of this sea. Alluvium is on the top of the Khvalynian section, it is contain rich complex of the freshwater and marine mollusc species (layer 5). Fluvial-marine deposits form the underwater delta, which accumulated during Late Khvalynian time. These deposits contain shell fragments of freshwater and marine mollusc species. Deposits of the underwater delta form in the relief elongated hills, which are known as "Ber bugor" among geomorphologists.

Keywords: palaeoecology; Quaternary; mollusks; Lower Volga; Northern Fore-Caspian Lowland.

\section{УДК 581.4 \\ АДАПТАЦИОННЫЕ МЕХАНИЗМЫ ФОРМИРОВАНИЯ ПОБЕГОВОЙ СИСТЕМЫ ОСОБИ БУДРЫ ПЛЮЩЕВИДНОЙ (GLECНОМА НЕDЕRАСЕА L.) В УСЛОВИЯХ МЕНЯЮЩИХСЯ ФАКТОРОВ ОКРУЖАЮЩЕЙ СРЕДЫ}

(C) 2015

\author{
В.И.Полуянова, кандидат биологических наук, доцент, \\ Н.В.Салахов, кандидат биологических наук, доцент \\ Казанский Федеральный университет, Казань (Россия)
}

\begin{abstract}
Аннотация. Вегетативно-подвижные растения - наиболее приспособленная в большинстве естественных фитоценозах и играющая важную роль в природе группа растений. В развитии вегетативно-подвижного растения характерно единство и противопоставление трех взаимосвязанных аспектов: вегетативного развития, генеративного размножения и вегетативного размножения. Разрешение противоречий между ними носит приспособительный характер. Вегетативное возобновление и размножение у вегетативно-подвижных растений сочетается со способностью к вегетативной подвижности, которая позволяет растению отодвигать свое вегетативно-дочернее потомство от материнского организма. Экологический и фитоценотический тропизм плагиотропных побегов позволяет растениям (статистически) рационально «выбирать» места для закрепления вегетативно-дочерних особей. Повышенная влажность почвы способствует размножению надземными укореняющимися побегами, а также заложению почек возобновления в тканях органов вегетативного размножения. Фактор влажности почвы является одним из решающих в комплексе различных экологических факторов при формировании внутренней структуры ползучего побега. Специфичность структуры побеговой системы будры плющевидной в различных
\end{abstract}


условиях имеет приспособительный характер как эволюционно закрепленная видовая особенность и как проявление пластичности растительного организма к меняющейся экологической обстановке. Вегетативное размножение связано с укоренением плагиотропных побегов, семенное - с формированием цветоносов в пазухах ортотропных побегов. Парциальные кусты остаются долго соединенными между собой коммуникационными участками плагиотропного побега. В условиях освоения нового субстрата при отсутствии конкуренции со стороны других видов растений будра плющевидная хорошо развивается и размножается в лучших условиях питания и увлажнения при полном освещении и рыхлости почвы

Ключевые слова: будра плющевидная; вегетативное размножение; плагиотропный побег; анатомическое строение; влажность почвы.

Проблема изучения растительного покрова, выявления природных растительных ресурсов, их охраны и рационального использования является центральной в силу ее большого практического и теоретического значения. Одной из форм сохранения биологического разнообразия растений является их интродукция в ботанические сады, где имеются не только научные и производственные возможности, но и созданы генетические фонды местной и мировой флоры. Актуальность интродукционной работы заключается в том, что коллекции и экспозиции растений, разных эколого-географических зон создают экспериментальную базу для изучения эколого-биологических особенностей растений, их экологической пластичности и познания биоразнообразия растительного мира.

Изучение эколого-биологических особенностей хозяйственно-ценных вегетативно-подвижных растений природной флоры Республики Татарстан - одно из направлений научной деятельности Ботанического сада Казанского Федерального университета [1-5].

Группа вегетативно-подвижных растений наиболее специфична, наименее изучена и наиболее трудна для исследования. Однако эта жизненная форма играет важную роль в сложении большинства фитоценозов и представляет большой интерес в практическом отношении, т.к. в нее входят многие кормовые, сорные, лекарственные и другие полезные или вредные растения. Поэтому без детального изучения аспектов жизнедеятельности вегетативно-подвижных растений невозможно рациональное использование луговых, лесных и других растительных сообществ в условиях все возрастающей антропогенной нагрузки. Кроме того, вегетативно-подвижные растения наиболее перспективны для стационарных наблюдений и экологических экспериментов благодаря постоянной обозримости (без нарушения) их вегетативноподвижных побегов, динамики их роста и развития. Специфичность структуры вегетативно-подвижных растений вызывает большой интерес у исследователей. Основным направлением некоторых работ является изучение механизмов адаптации к локальным условиям произрастания [6-8], а также создание имитационных моделей пространственного развития ценопопуляций с позиций метамерного (модульного) строения растений [9-17].

Цель настоящего исследования: выявить адаптационные механизмы образования побеговой системы будры плющевидной (Glehoma chederaceae L.) в условиях эксперимента. Исследования проводились летом 2014 г. на территории ботанического сада КФУ

Объект исследования - будраплющевидная (Glechoma hederacea L., сем. Lamiaceae), многолетнее, мезофильное, длиннопобеговое моноподиально нарастающее наземноползучее растение с укореняющимися четырехгранными плагиотропными побегами и приподнимающимися цветоносными побегами. Временами направление роста и положение в пространстве меняются: плагиотропный побег может некоторое время расти, приподнимаясь, но потом все равно полегает, иногда кончик растущего побега зарывается в субстрат, а потом снова выходит на поверхность. Плагиотропность роста побегов, плотно прижимающихся к субстрату, - необходимое условие для длиннопобеговых моноподиальных многолетних наземно-ползучих трав со вставочными соцветиями [18].
Будра плющевидная - лекарственное и декоративное растение. Она хорошо приживается и обладает высокой вегетативной подвижностью, прекрасно возобновляется, отличается долголетием. При соприкосновении междоузлий стебля с землей происходит укоренение. Будра плющевидная неприхотлива - это позволяет ей занимать берега рек, засушливые склоны и холмы, но лучше растет на рыхлых плодородных почвах с достаточным увлажнением [19]. В затененных участках сада будра незаменима как неприхотливая газонная трава. Она прекрасно устилает почву и не требует особенного ухода.

С целью выявить адаптационные механизмы формирования побеговой системы будры плющевидной и «реализации» наследственно закрепленных признаков в конкретных условия протекания онтогенеза провели экспериментальные исследования. Опыт проводился в четырех вариантах: 1) свет+полив; 2) свет+удобрение; 3) тень+полив; 4) тень+удобрение. В начале мая на среднесуглинистой почве были заложены опытные площадки 1х1 кв.м. Опыт проводился в трехкратной повторности. В центре каждой площадки в свежевскопанную почву посадили кусочки плагиотропного побега длиной 10 см. с почками и придаточными корнями, взятыми из чистой заросли будры плющевидной на окраине небольшого березняка.

Через каждые 7 дней площадки 1 и 3 дополнительно увлажняли: 1 ведро воды на кв/м., на площадки 2 и 4 добавляли комплексное удобрение «Рост» (5 мл на 3 л воды). Все растения хорошо прижились. В условиях полного света при дополнительном поливе и питании происходило интенсивное овладение территории (табл.1, рис.1). В варианте 1 (свет+полив) повышенная влажность способствовала быстрому укоренению растущего плагиотропного побега (обычная реакция вегетативно-подвижного растения на влажность почвы). Листья с широкими листовыми пластинками покрывали занятую территорию сплошным ковром. В варианте 2 (свет+удобрение) почвопокровную функцию растение выполняло за счет образования большого количества ползучих побегов с длинными междоузлиями. Очень сильное затенение подавляет образование плагиотропных побегов [20], что мы наблюдали в варианте 4 (тень+удобрение), однако повышенная влажность почвы в варианте 2 (тень +полив) позволила особи усилить процессы, ведущие к закреплению особи на данной территории, последующему перемещению и вегетативному размножению.

Таблица 1

Количественные показатели морфологических признаков особи будры плющевидной из различных вариантов опыта

\begin{tabular}{|cc|ccc|}
\hline Показатели & $\begin{array}{c}\text { Вариант 1 } \\
\text { Свет + полив }\end{array}$ & $\begin{array}{c}\text { В ариант 2 } \\
\text { Свет + удобрения }\end{array}$ & $\begin{array}{c}\text { В ариант 3 } \\
\text { Тень + полив }\end{array}$ & $\begin{array}{c}\text { В ариант 4 } \\
\text { Тень + удобрения }\end{array}$ \\
$\begin{array}{c}\text { Кол-во } \\
\text { междоузий }\end{array}$ & 76 & 97 & 10 & 5 \\
\hline $\begin{array}{c}\text { Длина } \\
\text { побегов (см) }\end{array}$ & 183 & 251 & 78 & 19 \\
\hline
\end{tabular}




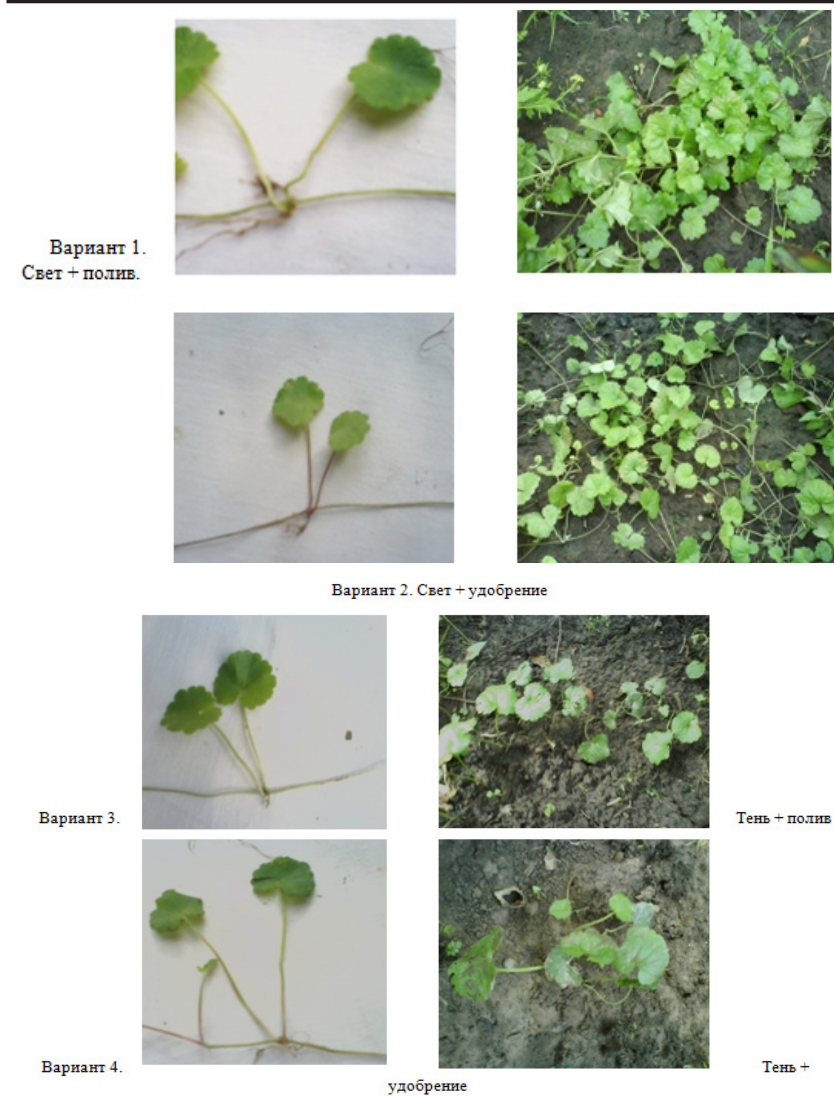

Рисунок 1 - Формирование побеговой системы особи будры плющевидной в различных вариантах опыта.

В условиях освоения нового субстрата при отсутствии конкуренции со стороны других видов растений будра плющевидная хорошо развивается и размножается в лучших условиях питания и увлажнения при полном освещении и рыхлости почвы.

Чтобы изучить внутреннюю структуру плагиотропного побега в различных вариантах опыта в сентябре с каждой особи были взяты модельные образцы для анатомических исследований. Кусочки побегов длиной 5 см брались у точки роста и в срединной части наземно-ползучего побега этого года нарастания. В последующем было сделано по 10 срезов с каждого образца, произведены измерения площадей тканей. При выборе анатомических признаков особое внимание было уделено тем, которые интегрально характеризуют строение побега и являются функционально существенными. На наш взгляд, к таким признакам относятся общая площадь поперечного среза и степень выраженности площадей тканей: паренхимы первичной коры, сердцевинной паренхимы, проводяще -механического кольца и центральной воздушной полости. После изготовления поперечных срезов снимались количественные показатели. Весь материал был статистически обработан и сфотографирован.

На поперечных срезах, сделанных у точки роста (Рис.2.1), проводящие элементы представлены протоксилемой и протофлоэмой, склеренхимная обкладка пучков не выражена, т.к. здесь постоянно идет формирование тканей ползучего побега. По мере удаления от точки роста увеличивается общая площадь среза, формируется склеренхимная обкладка проводящих пучков (Рис.2,пп). Четко выражены ребра. В ребрах обнаружено скопление толстостенных клеток уголковой колленхимы (Рис.2,к), опорной ткани, которая на всем протяжении ползучего побега образует тяжи. Она очень близка к паренхиме. В местах контакта эти ткани мало отличаются между собой, постепенно переходя одна в другую. Клетки паренхимы первичной коры, соседствующие с колленхимой, под гранями имеют хлоропласты, т.е. представляют собой ассимиляционную паренхиму (хлоренхиму).

Центральный цилиндр занимает третью часть среза (Рис.2,ц.ц). В срединной части побега, этого года нарастания, развитие тканей достигает максимального значения (Рис.2.2). Расстояние между пучками растет. За счет разрушения клеток сердцевинной паренхимы образуется воздухоносная полость.
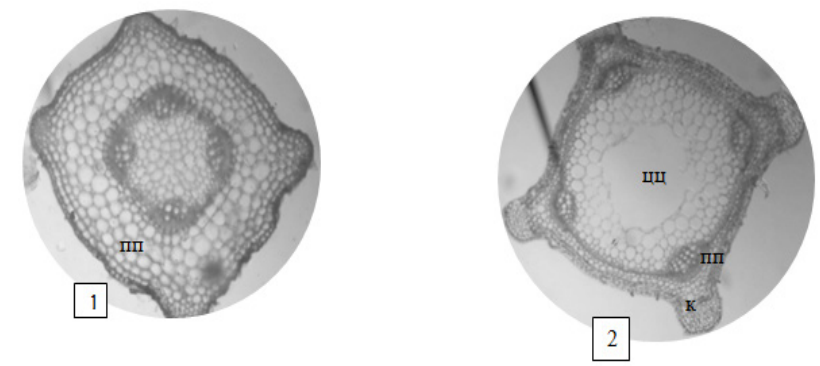

Рисунок 2 - Поперечные срезы плагиотропного побега будры плющевидной 1 - у точки роста; 2 - середина побега первого года нарастания

В таблице 2 показано, как в процессе формирования органа постепенно изменяется степень паренхиматизации побега и соотношение площадей тканей по вариантам опыта. По мере удаления от точки роста увеличивается общая площадь поперечного среза и меняется соотношение площадей отдельных тканей. Большую часть поперечного среза занимает паренхима первичной коры. Во втором варианте у точки роста на ее долю приходится более $50 \%$ от общей площади среза. По мере удаления от точки роста, активизируется деятельность камбия, увеличивается количество ассимилирующих листьев, возрастает площадь занятая проводящими элементами. Однако в процентном отношении такая закономерность четко не выражена. По-видимому, это связано с разной длиной междоузлий, размер которых зависит от микрорельефа местообитания и мощности особи. Повышение мощности слоя наружной паренхимы, проводящих и механических тканей в сухих условиях связано с необходимостью усиления защитных покровов против перегрева и обезвоживания. Возрастание доли паренхимной ткани при повышении увлажнения связано со стягиванием осевого цилиндра ближе к центру, благодаря чему орган становится более гибким, пластичным. Это предохраняет от разломов при перегибах, что очень важно для растений. В целом, значения площади паренхимы, отнесенные ко всей площади среза, показывают, что ткань проявляет большую специфичность распределения, что выделяет ее среди других признаков. Очевидно, это можно объяснить различным, функциональным значением клеток паренхимы в конкретных условиях. Однако данные относительного развития паренхимы показывают, что картина внутреннего распределения гистологических зон далеко не идентична их абсолютному развитию. При этом изменение паренхимы в системе тканей, слагающих побег, протекает не однотипно в разных частях побега и в разных вариантах опыта. Изменение площади паренхимы происходит как за счет центральной, так и коровой. Значения площади паренхимы, отнесенные ко всей площади среза, показывают, что доля площади паренхимы возрастает по градиенту увлажнения в средней части побега, в молодой части - снижается. Повышение мощности слоя наружной паренхимы в менее влажных условиях возникает с необходимостью усиления защитных покровов молодого побега. Эту функцию могут брать на себя клетки паренхимы. 
Таблица 2

Соотношение площадей тканей (среднее значение) на поперечных срезах плагиотропного побега будры плющевидной по вариантам опыта.

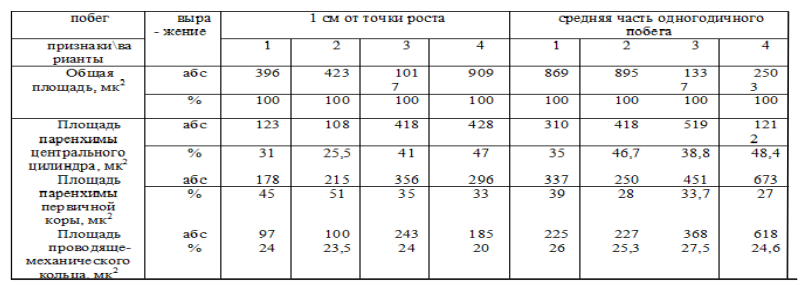

Анатомическая структура ползучего побега изменяется на протяжении его роста. В процессе формирования плагиотропного побега в изменяющихся условиях среды постепенно изменяется степень паренхиматизации органа и устанавливается соотношение характерное для строения наземноползучего побега. Процесс адаптации растений к условиям увлажнения и богатства почвы в условиях различной степени освещенности отражается на особенностях внутреннего строения отдельных зон плагиотропного побега. Изменение структуры отдельных зон в пределах побега носит количественный характер: по мере снижения влажности почвы увеличивается площадь проводяще-механического кольца и паренхимы, понижается аэренхиматизация побега, утолщаются покровные клетки. Однако степень пластичности каждого признака в различных частях побега не одинакова.

\section{СПИСОК ЛИТЕРАТУРЫ}

1. Полуянова В.И. К изучению экологии наземноползучих растений в условиях Волжско-Камского края // Региональные проблемы экологии. Казань: Татгосиздат, 1985. С. $88-89$.

2. Полуянова В.И. К экологической анатомии плагиотропного побега Veronica chamaedrys L. // Сборник научных трудов по материалам научнопрактической конференции «Современные проблемы и пути их решения в науке, транспорте, производстве и образовании». 15-25 декабря 2005 г. Т.11. Биология. Одесса, 2005. С. 7-9.

3. Полуянова В.И., Федорова С.В. Опыт выращивания Potentilla anserina L. в экспериментальных посадках (Республика Татарстан) // Растительные ресурсы. 2002. № 1. C. 57-64.

4. Любарский Е.Л. Экология вегетативного размножения высших растений. Казань: Изд. КГУ, 1967. $180 \mathrm{c}$.

5. Любарский Е.Л., Полуянова В.И. Изменчивость ценопопуляции клевера ползучего в условиях клинального фитоценоза // Экология. 1991. № 4. C.79- 1.6. Coles S. M. Ranunculus repens in Europe // Watsonia. 1977. T. 11. P. 353-366.

7. Sarukhan J., Harper J. 1. Studies on plant demography Ranunculus repens, R. bulbosus L. and R. acris. 1 . Population flux and survi, orschip // Ibid, 1973. Vol. 61. №4. P. 675-716.

8. Любарский Е.Л., Полуянова В.И. Структура ценопопуляций вегетативно-подвижных растений. Казань: Изд-во КГУ, 1984. 140 с.

9. Маркаров А.М. Подземный метамерный комплекс корневищных и столонообразующих травянистых многолетников // Научные доклады. Сыктывкар, 1994. Вып. 339. 20 с.

10. Илюшечкина Н.В. Структура полицентрических особей Anennaria dioica (L.) Gaertn // Известия СПбГАУ. Вып.17. 2009. С. 47-53.

11. Илюшечкина Н.В. Эколого-ценотическая характеристика и структура ценопопуляций Mercurialis perennis L. // Известия СПбГАУ. Вып.13. 2009. С. 26-29.

12. Дубровная С.А. Пространственно-временная неоднородность популяции земляники лесной (Fragaria vesca L.) - основа ее устойчивого состояния // Принципы и способы сохранения биоразнообразия: Материалы конф. Йошкар-Ола: Изд-во МарГУ, 2004. С. 204-205.

13. Федорова С.В. Внутрипопуляционные адаптации лапчатки гусиной // Биоразнообразие и биоресурсы Среднего Поволжья и сопредельных территорий. Казань. 2001. С. 83.

14. Серебрякова Т. И. Жизненные формы и модели побегообразования наземно-ползучих многолетних трав // Жизненные формы: структура, спектры и эволюция. М.: Наука, 1981. С. 161-179.

15. Кислюк О.С., Паленова М.М. Имитационное моделирование наземно-ползучих трав // Успехи экологической морфологии растений и ее влияние на смежные науки. М.: Прометей, 1994. С. 100-101.

16. Савиных Н.П. Поливариантность развития растений как следствие модульной организации // Поливариантность развития организмов, популяций и сообществ. Йошкар-Ола, 2006. С. 43-51.

17. Barthelemy D., Caraglio Y. Plant architecture: A dynamic, multilevel and comprehensive approach to plant form, structure and ontogeny // Annals of botany. 2007. Vol.99. P. 375-407.

18. Гатцук Л.Е. Содержание понятия «травы» и проблема их эволюционного положения // Проблемы экологической морфологии растений. М.: Наука, 1976. C. $55-130$.

19. Флора СССР. Т. ХХ. 1954. С.286 437.

20. Голубев В.Н. Эколого-биологические особенности травянистых растений и растительных сообществ лесостепи. М.: Наука, 1965. 287 с.

\section{ADAPTATION MECHANISMS OF FORMATION SPROUT SYSTEMS INDIVIDUALS GLECHOMA HEDERACEA L. UNDE CHANGING ENVIRONMENTAL FACTORS}

(C)2015

V.I. Poluyanova, candidate of biological sciences, associate Professor of the UOC «Botanical garden» Kazan (Volga region) Federal University, Kazan (Russia)

N.V. Salakhov, candidate of biological sciences, associate Professor of the UOC «Botanical garden» Kazan (Volga region) Federal University, Kazan (Russia)

Abstract. Vegetative-mobile plants - the fittest in most natural plant communities and plays an important role in the nature of a group of plants. In the development of vegetative-rolling plants is characterized by the unity and opposition of three interrelated aspects: vegetative development, generative and vegetative reproduction. The resolution of contradictions between them is adaptive in nature. Vegetative restoration and vegetative reproduction-moving plants combined with the ability to vegetative mobility, which allows the plant to push their vegetative-child offspring from the mother's body. Ecological and phytocoenotic tropism plagiotropic shoots allows plants (statistically) rationally «choose» places to secure autonomic-affiliated individuals. Increased soil humidity promotes the growth of aboveground rooting shoots, as well as the initiation of kidney regeneration in the tissues of the organs of vegetative reproduction. Factor soil moisture is a key in the set of different environmental factors in shaping the internal structure of creeping escape.

Specificity patterns sprout systems Glechoma hederacea in various conditions has adaptive nature enshrined as an evolutionary species feature and as a manifestation of plasticity of the plant organism to changing environmental conditions. 
Vegetative reproduction is associated with rooting plagiotropic shoots, seed - with the formation of stalks in the axils of orthotropic shoots. Partial bushes remain long interconnected by communication stations plagiotropic escape. In the development of a new substrate in the absence of competition from other plant species Glechoma hederacea well developed and propagated in the best conditions of nutrition and hydration in full light and the looseness of the soil

Keywords: Glechoma hederacea; plagiotropic escape; anatomical structure; the soil moisture; vegetative reproduction; soil moisture.

\title{
УДК $581.9(471.41 / 42)$ \\ ИТОГИ ФЛОРИСТИЧЕСКИХ ИССЛЕДОВАНИЙ РЕКИ СВИЯГИ В РАМКАХ ПРОЕКТА РГО «РЕКИ УЛЬЯНОВСКОЙ ОБЛАСТИ»
}

(C) 2015

\author{
Ульяновский государственный педагогический университет имени И.Н. Ульянова, Ульяновск \\ (Россия)
}

\begin{abstract}
Аннотация. В период с 23 мая по 1 июня 2014 г. состоялась третья экспедиция-сплав в рамках многолетнего профильного проекта «Реки Ульяновской области», которая в этом году прошла в рамках проекта Ульяновского отделения Русского географического общества «Комплексное экологическое обследование среднего течения реки Свияга». Проект «Реки Ульяновской области» рассчитан на 4 года и реализуется Ульяновским областным отделением Русского географического общества совместно с Симбирским отделением Союза охраны птиц России, Ульяновским областным краеведческим музеем им. И.А. Гончарова, Научно-исследовательским центром «Поволжье», Ульяновским государственным педагогическим университетом им. И.Н. Ульянова и Ульяновским государственным университетом. Основной целью научных исследований является - комплексная экологическая характеристика крупных и средних рек Ульяновской области, оценка их современного экологического, химического состояния и биотического разнообразия. В 2014 г. году исследования проводились на реке Свияге по следующим направлениям: ботаника, энтомология, ихтиология, орнитология, териология и гидрология. Помимо этого, проведено современное ландшафтное описание поймы и долины реки Свияги, а также дана характеристика динамики антропогенной нагрузки на водоём. В данной статье приводятся результаты ботанических исследований реки Свияги, даются геоботанические и флористические описания объекта исследования с выделением наиболее раритетных растительных объектов, которые могут дополнить данные региональной Красной книги.
\end{abstract}

Ключевые слова: флора; фитоценоз; река Свияга; экспедиция; редкие растения; охраняемые растения; сплав; биологическое разнообразие; памятник природы; речной бассейн.

В период с 23 мая по 1 июня 2014 г. состоялась третья экспедиция-сплав в рамках проекта «Малые реки Ульяновской области», которая в этом году прошла в рамках проекта Русского географического общества «Комплексное экологическое обследование среднего течения реки Свияга». Основной целью научных исследований является получение комплексной экологической характеристики крупных и средних рек Ульяновской области, оценки их современного состояния и биотического разнообразия. В 2014 г. году исследования проводились на реке Свияге по следующим направлениям: ботаника, энтомология, ихтиология, орнитология, териология и гидрология. Помимо этого, проведено ландшафтное описание поймы и долины Свияги, а также дана характеристика антропогенной нагрузки на водоём.

Маршрут экспедиции пролегал по двум субъектам Российской Федерации: Ульяновской области (189 км) и республики Татарстан (12 км). Начальной точкой сплава стало с. Чириково Кузоватовского p-на Ульяновской области, конечной - с. Вожжи Тетюшского p-на республики Татарстан. За 10 дней пройден 201 км русла Свияги, обследованы пойменные и долинные ландшафты реки (рис. 1). Дневные переходы по реке осуществлялись на байдарках и составили в среднем 20 км в день (с разбросом от 8,9 км до 37,4 км).

На каждой стоянке проводился организовывались пешие рекогносцировочные обследования долинных участков реки по общепринятым методикам [1,с. 208; 11 , с.244; 21 , с. $200 ; 20$, с. 50]. Гербаризация растений осуществлялась по общепринятым методикам [3, с.52; 11 , с. $244 ; 13$, с. $199 ; 14$, с. 88$]$. Камеральная обработка материала велась на кафедре ботаники естественногеографического факультета Ульяновского государственного педагогического университета им. И.Н. Ульянова.

Определение видов проводилось при помощи следующих сводок: «Флора СССР» [19], «Флора Европейской части СССР (позже - Флора Восточной Европы» [16; 17], «Флора средней полосы Европейской части СССР [8], «Флора средней полосы Европейской части России» [9], «Определитель сосудистых растений центра Европейской части России» [18], «Определитель растений Среднего Поволжья» [2], «Флора и растительность Татарской АССР» [18].

Свияга - правый приток Волги. В истоках находятся родники из водоносных пластов палеогена близ села Кузоватово, устье - в г. Свияжске Республики Татарстан. Направление течения реки - с юга на север, в верховьях - с юго-запада на северо-восток Общая длина Свияги - 375,2 км, в пределах Ульяновской области - 190,4 км. Площадь всего бассейна - 17838 км2, он ассимметричен, около 75\% воды Свияга получает с левобережной части, где имеются крупные притоки: Малая Свияга, Гуща, Сельдь, Бирюч, Бугурна [4, с. 240; 12 , с.327; 15 , с. 196].

Как видно из небольшой географической справки, в ходе экспедиции удалось пройти большую часть основного русла реки и «затронуть» всю Свиягу, протекающую, в основном, по территории Ульяновской области

Начальной точкой экспедиции послужил нарушенный остепненный луг близ с. Чириково Кузоватовского района Ульяновской области (рис. 2).

На обследованном участке река Свияга в верхнем течении протекала среди лесостепных ландшафтов - небольших пойменных лесов, чаще всего ивняков и ольшаников (ольшаник осоковый, ольшаник снытеворазнотравный). На возвышенных рельефах реки доминировали лугово-степные типы сообществ, чаще мятлико- и осоково-разнотравные. По мере удаления на запад от основного русла реки встречаются сосняки, в понижениях сосново-березовые и сосново-осиновые леса, на возвышенных участках с примесью дуба, липы и клена. Здесь в формировании растительного покрова наряду с типичными неморальными принимают участие и бореальные виды (Cystopteris fragilis, Diphasiastrum complanatum, Dryopteris austriaca, Matteuccia struthiopteris, Pyrola chlorantha, Trollius europaeus, Oxycoccus palustris), обитающие в основном по тенистым оврагам и балкам. 